\author{
Dave E. Marcial \\ Associate Professor, Ph.D. in Education, Dean \\ Silliman University, Dumaguete City, Negros Oriental, Philippines \\ demarcial@su.edu.ph \\ Dae P. Habalo \\ Master in Business Administration, Senior Education Program Specialist \\ Department of Education Division of Negros Oriental, Philippines \\ ORCID iD 0000-0003-1101-2130 \\ dphabalo@gmail.com
}

\title{
SUCCESS LEVEL OF A HYBRID TRAINING IN TEACHER EDUCATION: EXPERIENCES IN A DEVELOPING COUNTRY
}

\begin{abstract}
Studies show that blended learning promotes collaborative learning. However, blended learning is always a challenge when Internet infrastructure is limited. This paper describes the success levels of the 6-month blended learning course for teacher educators in four provinces in the central part of the Philippines. The blended training was aimed to increase the ability to add value to economic output by applying knowledge of school subjects to solve complex problems encountered in the real world situations of work and life. Success levels were measured using retention rate, Constructivist Online Learning Environment model, Online Environment Elements model, and New Kirkpatrick Model. Of the 60 registered teacher-trainees, only 15 completed the training. It was concluded that the blended training was evaluated very successfully.
\end{abstract}

Keywords: Blended Training; Educational Technology; ICT in Teacher Education.

\section{INTRODUCTION}

"Blended learning, also referred to as hybrid learning, combines traditional face-to-face classroom instruction with online learning" [1]. "It provides higher education institutions with the opportunities to enhance the quality of teaching and learning" [2]. Blended learning helps augment the professional development for teachers. It emphasizes multi-learning channel among teachers [3].

In 2012, the Philippine's Commission on Higher Education (CHED) established a research platform called Philippine Higher Education Research Network (PHERNet). The network is composed of ten private and public universities in the Philippines. Silliman University (SU), a non-sectarian university, is a member institution because of its track record in research and development. Further, PHERNet is tasked to research the priority areas of the National Higher Education Research Agenda 2, in which education and information technology are among the said priority research areas. Motivated by the technology diffusion encountered by teacher educators and the opportunity offered by PHERNet, a research was proposed and funded by CHED. The research is entitled "ICT in Teacher Education in Region 7". The study is facilitated by SU through Research and Development Center and in cooperation with the Center of Development in IT Education of the College of Computer Studies of the same university. The study highlights four (4) phases; these are benchmarking, training, technology development, and evaluation. The benchmarking phase aimed to assess the landscape of the ICT in the teacher education programs in Region 7 using the international and national competency standards. Training period intended to offer an ICT competency enhancement training program for the pilot group of teachers in the teacher education program in region 7 . Technology development phase aims to develop two tools for teachers in the education program; these are portable learning management system and a mobile application for teacher educators. Evaluation phase seeks to measure the competency among 
the respondents after the competency enhancement training. It also aims to evaluate the acceptance level of the two proposed tools as perceived by the pilot group of users.

The training phase of the project is called ICT Skills Enhancement Program, dubbed as ICT4TEd. It is divided into two subphases: face-to-face and blended. Phase 1 training was conducted in May 2013 while phase 2 training was hybrid, which means the training was delivered in face-to-face and virtual or online modes. The 6-month blended learning was held in June to November 2013.

The training program is about ICT skills enhancement in the teacher education in Region 7, Philippines. Teacher education refers to degree programs such as Bachelor of Science in Secondary Education and Bachelor of Science in Elementary Education offered in public and private HEIs. Phase 2 training is free, and it was conducted by a hybrid method of delivery. It is designed for teachers in the teacher education program who have undergone the five-day Phase 1 training. It was aimed to increase the ability of the teachers to add value to economic output by applying knowledge of school subjects, to solve complex problems encountered in the real world situations of work and life. Trainees were expected to have enhanced skills in ICT in all aspects of their teaching responsibilities: policy, curriculum and assessment, pedagogy, organization and administration, and teacher professional development.

A need-based training module was designed, and it was based on the result of the region-wide assessment conducted in April 2013. It was organized by topic, objective, resources, and weekly activities. 15 topics were included for the skills development in the knowledge deepening level as described by UNESCO. Each item was delivered in an average of one week. Each topic has a corresponding activity that is to be performed and submitted by the trainees through the submission link provided in the learning management system.

The online or virtual component of the blended learning was delivered through a learning management system of Silliman University as the host university. The learning management system is called Silliman Online University Learning (SOUL). SOUL is customized using Moodle platform. All participants were oriented to the use of SOUL during the phase 1 training in May 2013. A Facebook group was also created to supplement the delivery of the online or virtual training. All participants were invited to become a member of the said group. Participants were encouraged to post some discussion notes, chat with colearners and email to support the virtual delivery of the training. All resources were posted in SOUL while announcements and reminders were posted on the Facebook page. Weekly reminders were also sent through mobile SMS. Moreover, technical support was provided $24 / 7$ via email and mobile communication.

A face-to-face meeting and training were conducted to supplement the online training. It was a two-day activity with a twofold objective held on September 13-14, 2013. On the first day, a review and feedbacking of the previous topics, as well as completion of the previous online activities were done. On the second day, an overview and introduction to the remaining topics were conducted. The midterm face-to-face meeting ended with hands-on training in website creation. At the end of the training, all trainees created their educational website using a free website builder offered for free at www.education.weebly.com. Participants during the mid-term review are only those who completed the activities from week 1 to 10 . In this case, 15 trainees were invited to the face-to-face mid-term review and the website creation training.

In the same manner, a culminating activity was conducted face-to-face for two days. Review, finalization of activities, and reflection-sharing were the significant events during the culmination. There were also keynote speeches and presentations from notable advocates of ICT in education. The culmination program ended with an action planning by all trainees who completed the skills enhancement training. 
The problem statement. Studies show that hybrid training offers significant challenges for learners, training providers, trainers, and other stakeholders. These challenges include technical, organizational and instructional design [4]. Likewise, organizational blended learning poses challenges that can create barriers to learning success [5]. These challenges include a) the challenge of too much too soon, b) the challenge of traditional mindset, c) the challenge of misdirected strategy, d) the challenge of managing and assessing learner progress, and e) the challenge of bringing all elements of the blend together.

The hybrid training "ICT Skills Enhancement Program" was an attempt to provide new and innovative professional development among teachers. It was a known fact that majority of the teachers who attended the training did not have prior experience in hybrid learning. Thus, measuring and documenting the success level of the program was very vital for the training providers, the funders, and other stakeholders. It is hoped that this article will contribute to the limited literature of hybrid training among teachers in the Philippines.

The article's goal. The goal of this paper is to present the success levels of the 6-month blended training among teacher educators in the Philippines. Specifically, this paper aims to answer the following questions: 1) What is the retention rate of the participants in the training? 2) What is the success level of the training according to the factors in a constructivist online learning environment? What is the success level of the training regarding the online environment elements? What is the success level of the training according to the New Kirkpatrick Model?

\section{RESEARCH METHODS}

In the training, the success level is measured in four different models. These are 1) retention rate, 2) Constructivist On-Line Learning Environment Survey (COLLES), 3) Online Environment Evaluation (OEE) Model and 4) New World Kirkpatrick Model. The retention rate is computed by getting the total number of registered trainees divided by the number of trainees who completed the training. The Constructivist On-Line Learning Environment Survey (COLLES) measures the learners' perceptions of both their preferred and actual online training environments. It is a feature embedded in the Moodle platform, which means that the COLLES evaluation was adopted and done virtually through SOUL. The COLLES is composed of 24 statements grouped into six parts [6]. Each of elements is designed to assess the quality of the online training environment. These elements are relevance, reflection, interactivity, tutor support, peer support, and interpretation. The COLLES comprises a fivepoint Likert-type response scale. Each scale has a corresponding score, 1, 2, 3, 4, 5 for almost never, seldom, sometimes, often, and almost always, respectively.

The second model used in determining the success of the training is the Online Environment Evaluation (OEE). OEE aims to measure the effectiveness of the online training course based on the principles of online design. The OEE questionnaire is adapted from an online course evaluation published on the website [7]. The OEE questionnaire comprises 37 questions grouped into four elements. These elements are instructional design features, interaction and feedback, course management, and technical support. Using Google Form, all trainees were asked to rate the level of effectiveness of the online training course using the five-point Likert scale as follows: 5 - almost always, 4 - often, 3 - sometimes, 2 - seldom, and 1 -almost never. The second part of OEE questionnaire is composed of seven open-ended questions to allow the trainees provide qualitative feedback and assessment.

The third model used in evaluating the success of the training is the Kirkpatrick Model (KM). KM was developed in the 1950s and presently clarified with the New World Kirkpatrick Model. On the website of Kirkpatrickpartners.com, the four (4) levels of evaluation are explained. The first level is the reaction in terms of satisfaction, engagement, 
and relevance. Level 2 is the extent of learning that participants acquire the intended knowledge, skills, attitudes, confidence and commitment based on their participation in a training activity. The third level is the degree that participants apply what they learned during training when they are back to their work. Level 4 is the results in terms of the degree of targeted outcomes occurring as a result of the training event and subsequent reinforcement. The KM questionnaire is composed of 16 close-ended questions that represent the four levels described in the New World Kirkpatrick Model. Using Google Form, all trainees were asked to rate the level of their agreement with the statements adapted from the New World Kirkpatrick Model. All trainees have been invited to rate using the four choices: strongly agree, agree, disagree, and strongly disagree.

All questionnaires were scrutinized and underwent a thorough critiquing and modification. Mean, frequency and percentage are the statistical tools employed in the analysis of data in the three evaluations. Respondents of the three questionnaires are those who have completed the entire blended learning. Only 14 responses were recorded and analyzed because one trainee failed to answer the online evaluation at the specified date.

\section{THE RESULTS AND DISCUSSION}

\subsection{Trainee's demographic profile}

ICT4TEd trainees are full-time faculty members teaching professional, specialization and major courses in the teacher education program in Central Visayas. A total of 60 trainees were invited and registered in SOUL. The creation of accounts and the online registration were done during the last day of the phase 1 training. Sixteen joined in Negros Oriental; 28 joined in Cebu and 16 joined in Bohol. Of the total number of trainees, $22(37.7 \%)$ are male, and $38(63.3 \%)$ are female. Twenty $(38.8 \%)$ trainees are 31-40 years old; the youngest is 22 years old, and the oldest is 64 years old. Regarding the number of years of teaching, 35 years is the longest teaching experience while one year is the shortest. More than the majority of the respondents are married, and many are Master's degree holders. See table 1 in the demographic profile of the registered trainees.

When asked about technology ownership, $38(68.0 \%)$ responded that they own a desktop computer at home, of which $29(51.9 \%)$ with an internet connection (see table 2). Only 24 (39.9\%) have Smartphones, but all of the respondents have cellular phones. Only 9 $(15.6 \%)$ said that they had tablet computers, and $44(78.8 \%)$ said that they owned a laptop or notebook computers. Only $49(92.1 \%)$ said that their school was connected to the Internet; 52 $(95.8 \%)$ stated that they created an email account, and $24(39.4 \%)$ stated that they opened their account at least once a day. Furthermore, 40 (67.3\%) trainees stated that they had never attended a similar training like this in the past (see table 2). Only $11(19.7 \%)$ trainees said that they had attended a similar training in the past while $7(13.0 \%)$ trainees did not indicate whether they had attended ICT-related training in the past.

Table 1

Demographic Profile of the Registered Participants

\begin{tabular}{|c|c|c|c|c|c|c|c|c|c|}
\hline \multirow{3}{*}{ Profile } & & \multicolumn{6}{|c|}{ Batch of Trainees } & \multirow{2}{*}{\multicolumn{2}{|c|}{ Total }} \\
\hline & & \multicolumn{2}{|c|}{$\begin{array}{l}\text { Negros } \\
\text { Oriental } \\
\end{array}$} & \multicolumn{2}{|c|}{ Cebu } & \multicolumn{2}{|c|}{ Bohol } & & \\
\hline & & $\mathbf{f}$ & $\%$ & f & $\%$ & f & $\%$ & f & $\%$ \\
\hline \multicolumn{10}{|l|}{$\underline{\operatorname{Sex}}$} \\
\hline Male & & 8 & 50.0 & 6 & 21.4 & 8 & 50.0 & 22 & 36.7 \\
\hline \multirow[t]{2}{*}{ Female } & & 8 & 50.0 & 22 & 78.6 & 8 & 50.0 & 38 & 63.3 \\
\hline & Total & 16 & 100.0 & 28 & 100.0 & 16 & 100.0 & 60 & 100.0 \\
\hline
\end{tabular}




\begin{tabular}{|c|c|c|c|c|c|c|c|c|c|}
\hline \multicolumn{10}{|l|}{ Age } \\
\hline$\overline{21-30}$ & & 2 & 12.5 & 8 & 28.6 & & & 10 & 16.7 \\
\hline $31-40$ & & 7 & 43.8 & 8 & 28.6 & 5 & 31.3 & 20 & 33.3 \\
\hline $41-50$ & & 4 & 25.0 & 2 & 7.1 & 1 & 6.3 & 7 & 11.7 \\
\hline$>51$ & & 2 & 12.5 & 3 & 10.7 & 3 & 18.8 & 8 & 13.3 \\
\hline \multirow[t]{2}{*}{ No Answer } & & 1 & 6.3 & 7 & 25.0 & 7 & 43.8 & 15 & 25.0 \\
\hline & Total & 16 & 100.0 & 28 & 100.0 & 16 & 100.0 & 60 & 100.0 \\
\hline \multicolumn{10}{|c|}{ Number of years in teaching } \\
\hline$<4$ & & 1 & 6.3 & 11 & 39.3 & 2 & 12.5 & 14 & 23.3 \\
\hline $4-6$ & & 2 & 12.5 & 4 & 14.3 & 3 & 18.8 & 9 & 15.0 \\
\hline $7-9$ & & 3 & 18.8 & 1 & 3.6 & 1 & 6.3 & 5 & 8.3 \\
\hline $10-15$ & & 2 & 12.5 & 3 & 10.7 & 2 & 12.5 & 7 & 11.7 \\
\hline $16-20$ & & 3 & 18.8 & & 0.0 & 1 & 6.3 & 4 & 6.7 \\
\hline$>21$ & & 2 & 12.5 & 6 & 21.4 & 1 & 6.3 & 9 & 15.0 \\
\hline \multirow[t]{2}{*}{ No Answer } & & 3 & 18.8 & 3 & 10.7 & 6 & 37.5 & 12 & 20.0 \\
\hline & Total & 16 & 100.0 & 28 & 100.0 & 16 & 100.0 & 60 & 100.0 \\
\hline \multicolumn{10}{|l|}{ Status } \\
\hline$\overline{\text { Single }}$ & & 6 & 37.5 & 12 & 42.9 & 1 & 6.3 & 19 & 31.7 \\
\hline Married & & 9 & 56.3 & 12 & 42.9 & 10 & 62.5 & 31 & 51.7 \\
\hline Widowed & & & 0.0 & 1 & 3.6 & 1 & 6.3 & 2 & 3.3 \\
\hline \multirow[t]{2}{*}{ No Answer } & & 1 & 6.3 & 3 & 10.7 & 4 & 25.0 & 8 & 13.3 \\
\hline & Total & 16 & 100.0 & 28 & 100.0 & 16 & 100.0 & 60 & 100.0 \\
\hline \multicolumn{10}{|c|}{ Highest Educational Attainment } \\
\hline Bachelor & & 4 & 25 & 5 & 19 & & & 9 & 14.7 \\
\hline Master's Degree & & 7 & 43.8 & 5 & 19 & 4 & 33 & 16 & 32.1 \\
\hline Doctoral/Ph.D. & & 3 & 18.8 & 5 & 19 & & & 8 & 12.7 \\
\hline \multirow[t]{2}{*}{ No Answer } & & 2 & 12.5 & 11 & 42 & 8 & 67 & 21 & 40.5 \\
\hline & Total & 16 & 100 & 26 & 100 & 12 & 100 & 54 & 100.0 \\
\hline
\end{tabular}

ICT Literacy Profile of the Registered Participants

Table 2

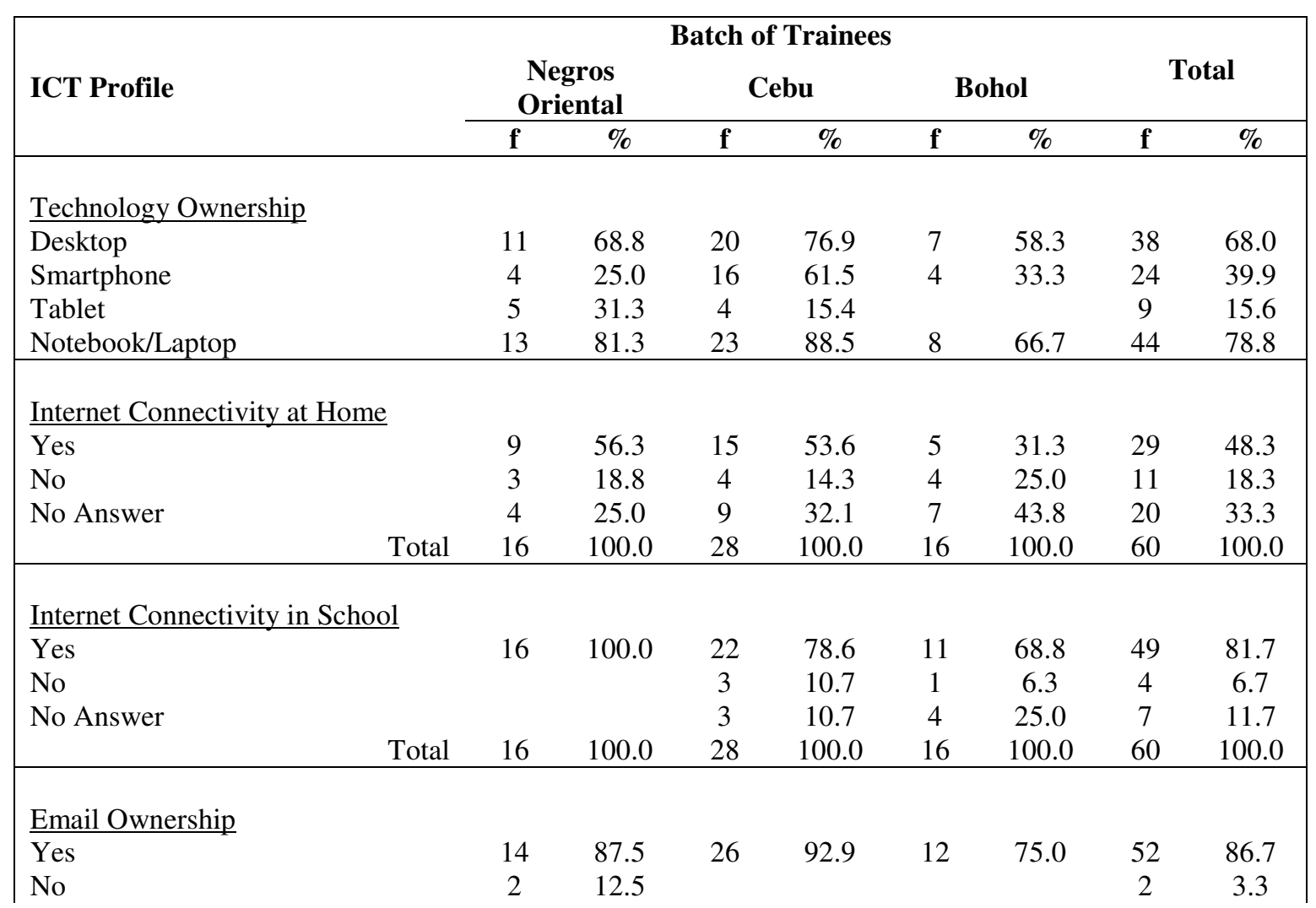




\begin{tabular}{|c|c|c|c|c|c|c|c|c|c|}
\hline No Answer & Total & 16 & $\begin{array}{c}0.0 \\
100.0 \\
\end{array}$ & $\begin{array}{c}2 \\
28 \\
\end{array}$ & $\begin{array}{c}7.1 \\
100.0 \\
\end{array}$ & $\begin{array}{c}4 \\
16 \\
\end{array}$ & $\begin{array}{c}25.0 \\
100.0 \\
\end{array}$ & $\begin{array}{c}6 \\
60 \\
\end{array}$ & $\begin{array}{c}10.0 \\
100.0\end{array}$ \\
\hline \multicolumn{10}{|c|}{ Number of times in opening email account } \\
\hline At least once a day & & 7 & 43.8 & 15 & 53.6 & 2 & 12.5 & 24 & 40.0 \\
\hline At least once a week & & 2 & 12.5 & 9 & 32.1 & 5 & 31.3 & 16 & 26.7 \\
\hline At least once a month & & 2 & 12.5 & 2 & 7.1 & 3 & 18.8 & 7 & 11.7 \\
\hline At least once a semester & & 1 & 6.3 & & 0.0 & 1 & 6.3 & 2 & 3.3 \\
\hline At least once in an SY & & 4 & 25.0 & & 0.0 & 1 & 6.3 & 5 & 8.3 \\
\hline No Answer & & & 0.0 & 2 & 7.1 & 4 & 25.0 & 6 & 10.0 \\
\hline & Total & 16 & 100.0 & 28 & 100.0 & 16 & 100.0 & 60 & 100.0 \\
\hline
\end{tabular}

\subsection{Success level of the training}

\subsubsection{Retention Rate}

As discussed earlier, there were 60 teacher educators invited and registered in SOUL. Of the 60 , only $15(25 \%)$ teacher-trainees were given a certificate of completion. The completion signifies that they have successfully performed all the activities from week 1 to 18 and completed the ICT skills enhancement training program that is delivered in blended mode. This result is just one of the many examples of low retention in online learning. Topdegreeonline.org asserts that, in general, the retention rates for online courses have been calculated to be 10 to $20 \%$ lower than the retention rates of the face-to-face learning. In the same manner, the US News and World Report announced that the average retention rate among first-time part-time students is 39\% [8]. According to an article by Rob Jenkins in the Chronicle of Higher Education, cited in [9], "students were more likely to fail or withdraw from online courses than for face-to-face courses, regardless of their initial level of preparation." The result can be associated with the ICT4TEd blended learning where the teacher educators are considered trainees or students on a part-time basis. On the positive note, the result is reasonable considering that more than the majority $(67.3 \%)$ are new to online learning and at the same time they are challenged with the technical skills. It can be recalled that these trainees have not experienced the actual process of ICT operations relevant to teaching-learning integration. The result is also reasonable considering the technical limitations among the trainees personally and institutionally. To recall, only $38(68.0 \%)$ of the trainees own a desktop computer at home, of which 29 (51.9\%) with an Internet connection. The study [10] asserts that "retention in massive open online courses (MOOC) should be viewed in the appropriate context, the apparently low retention in MOOCs is often reasonable." The authors strongly recommended that there must be a consideration in the framework of the learner intent.

If Coursera experienced around 60\% returnees during the first lecture, almost $100 \%$ of the ICT skills enhancement trainees returned and logged to SOUL and performed the first weekly activity. Around $17 \%$ of the trainees logged to SOUL until the midterm period but have not submitted any activities. Based on the initial interview, problems of Internet connectivity and preoccupation with work and at home are the common reasons why the others have not completed phase 2 training.

Shown in table 3 is the profile of the teacher-trainees who completed phase 2 training. As shown in the table, $10(66.67 \%)$ are female; $9(60 \%)$ are married; $9(60 \%)$ are aged 19 40; $9(60 \%)$ have Master's degrees, and $11(73.33 \%)$ are coming from the private higher education institution. In terms of the total number of HEIs, there are 13 because there are two schools with two trainees. It can be noted that no one from Siquijor completed the blended learning. Based on the first interview, the trainees from Siquijor are challenged with Internet connectivity. 
Table 3

Profile of the Trainees Who Successfully Completed the Training

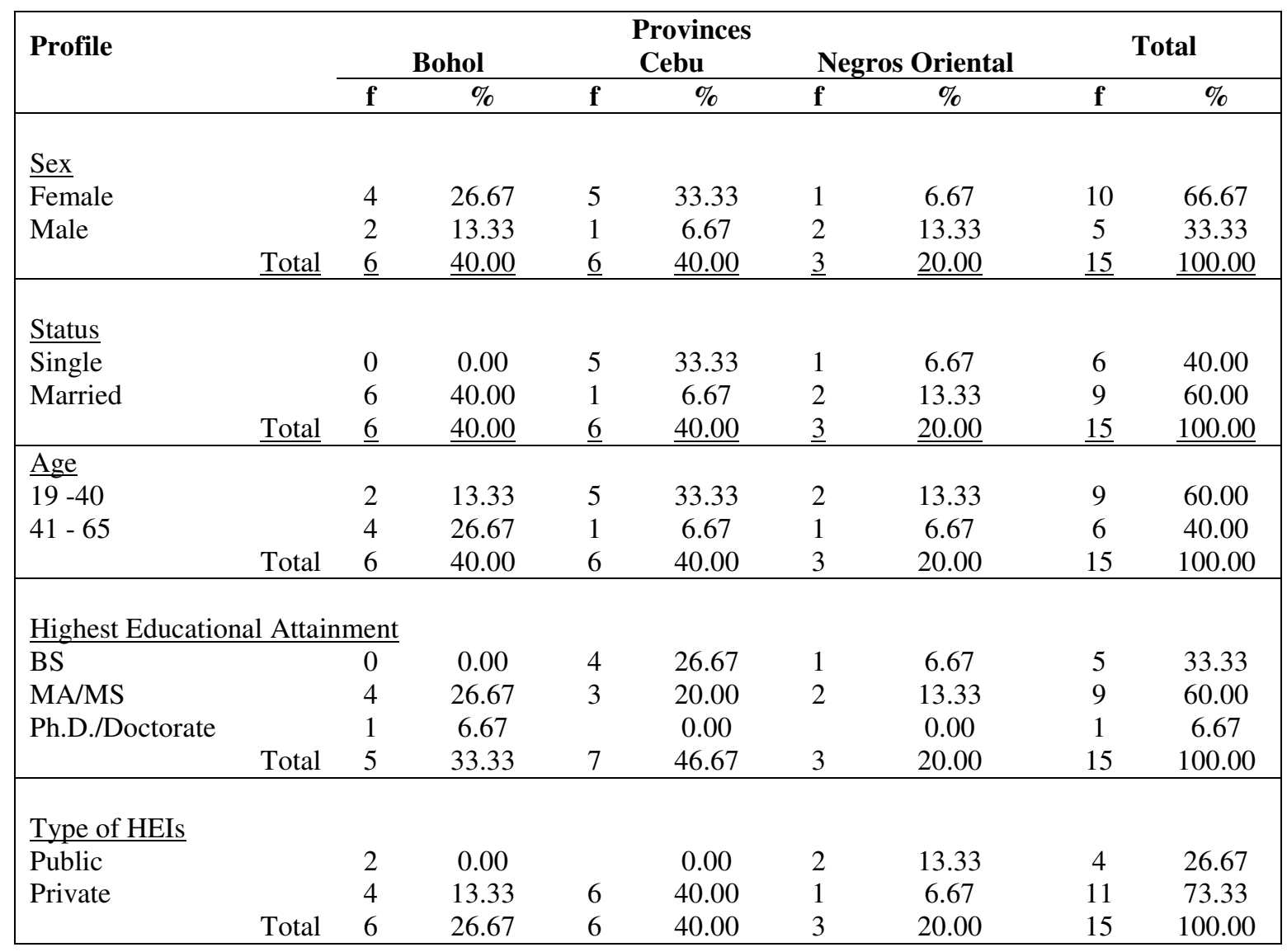

\subsubsection{COLES}

The summary of COLES result is shown in table 4. The quality of the online learning environment (SOUL) is very high with an aggregate mean of 4.37 and 4.64 for preferred and actual, respectively. The result implies that the online learning component of the training is highly relevant to the trainee's professional development. It also suggests that the online learning stimulated the trainee's critical reflective thinking. The result also suggests that the extent of interactivity among the trainees is very great, and the trainees believed that they highly engaged in productive conversation with co-trainees. The result suggests that the tutor support highly encouraged the trainees to participate and finish the program. The lowest mean of the elements in both preferred and actual evaluation is on peer support. The result means that the trainees did not highly expect to be assisted or supported by fellow trainees. Moreover, the result shows that the trainees and the tutor made a good sense of each other's online communication. It can also be seen that there is a positive mean difference between actual and preferred experience in the online component of the training.

Table 4

Summary of the Constructivist Online Learning Environment Survey Result

\begin{tabular}{|ccccc|}
\hline \multirow{2}{*}{ Elements } & \multicolumn{2}{c}{ Preferred } & \multicolumn{2}{c|}{ Actual } \\
\cline { 2 - 5 } & $\overline{\mathbf{x}}$ & Description & $\overline{\mathbf{x}}$ & Description \\
\hline Relevance & 4.60 & Almost Always & 4.84 & Almost Always \\
Reflective thinking & 4.29 & Almost Always & 4.74 & Almost Always \\
Interactivity & 4.27 & Almost Always & 4.53 & Almost Always \\
Tutor support & 4.48 & Almost Always & 4.73 & Almost Always
\end{tabular}




\begin{tabular}{|ccccc|} 
Peer support & 4.09 & Often & 4.38 & Almost Always \\
Interpretation & 4.46 & Almost Always & 4.63 & Almost Always \\
Aggregate Mean & $\mathbf{4 . 3 7}$ & Almost Always & $\mathbf{4 . 6 4}$ & Almost Always \\
\hline
\end{tabular}

\subsubsection{Online Environment Evaluation}

As shown in table 5, the online training environment is rated with an aggregate mean of 4.91 described as "almost always." The result suggests that the principles of online design are excellently integrated with the online learning. The result suggests that the instructional elements of the online training such as audience analysis, training course objectives, instructional activities, and teaching strategies are excellently achieved. It also entails that the trainees excellently experienced a positive interaction and collaboration among co-trainees and online tutor or instructor. The result also means that the training course was managed excellently, particularly in monitoring requirements of the trainees, their progress as well as in providing adequate feedback. Moreover, the result also indicates that the technical support for the trainees was excellent.

Table 5

\section{Summary of the Online Environment Evaluation Result}

\begin{tabular}{|ccl|}
\hline Summary & $\overline{\mathbf{x}}$ & Description \\
\hline Instructional elements & 4.85 & Almost Always \\
Interaction and feedback & 4.91 & Almost Always \\
Course management & 4.91 & Almost Always \\
Technical support & 4.96 & Almost Always \\
Aggregate Mean & $\mathbf{4 . 9 1}$ & Almost Always \\
\hline
\end{tabular}

\subsubsection{New World Kirkpatrick Model}

Using the New World Kirkpatrick Model, the trainees strongly agree that the training was effective with an aggregate mean of 3.90 (table 6). The result implies that the training was highly effective. The result suggests that the trainees are highly satisfied with the training and actively collaborated with the entire training program. Moreover, the result indicates that the trainees highly believed that they could use or apply what they learned in training on their teaching job. It also shows that the trainees have acquired the intended knowledge, skills, attitudes, confidence and commitment from the training. It also indicates that the required drivers for motivation were present during the training delivery. It also suggests that the trainees have a positive behavior to apply what they have learned from the training. Most importantly, the result denotes that the targeted training outcomes are highly achieved.

Table 6

Summary of the Training Evaluation Result

\begin{tabular}{|ccl|}
\hline Summary & $\overline{\mathbf{x}}$ & Description \\
\hline Reaction & 3.96 & Strongly Agree \\
Learning & 3.84 & Strongly Agree \\
Behavior & 3.86 & Strongly Agree \\
Results & 3.93 & Strongly Agree \\
Aggregate Mean & $\mathbf{3 . 9 0}$ & Strongly Agree \\
\hline
\end{tabular}


In response to the question "This course could be improved by," a trainee said that this course could be enhanced by providing the trainees with appropriate technology or gadget. Three of the trainees felt that frequent updates and collaboration would keep them abreast with the new ICT approaches in their classroom. Another trainee suggested that a needs assessment be conducted to gauge his knowledge on ICT. On the other hand, two trainees said that training should be continuous, and basics of HTML should be included. Surprisingly, a trainee believed that the course is designed to provide a holistic improvement of Education teachers like them. This further implies that the course is well-designed and very appropriate for teachers in Education Technology. Finally, when the trainees were asked the question "Do you have any other comments?" three proudly expressed their gratitude for being a pioneering member of the renowned group - ICT4TED. A trainee, however, encouraged the project leader to continue his advocacy to promote quality education most especially in the Education Technology subject. Another trainee said that the online course is a state of the art teachinglearning opportunity that combats old or traditional teaching methods. The trainees are undivided in showing their heartfelt gratitude to the project leader, CHED, Silliman University, the organizing team and other partner institutions for the one of a kind training. This particular finding signifies that the trainees are satisfied with the training provided and are eager to enhance their knowledge of ICT to become globally competent.

\section{CONCLUSIONS AND PROSPECTS FOR FURTHER RESEARCH}

The ICT skills enhancement program in the region was the first ever training to be delivered in a hybrid method of learning. It was a remarkable and challenging experience not only for the trainees but the organizers as well. It can be concluded that despite technological barriers, the training was a big success, and the training outcomes were highly achieved. The teachers widened their knowledge on integrating ICT in the aspects of educational policy, curriculum and assessment, pedagogy, tools, organization and administration, and teacher professional development.

To sustain the learned skills, trainees must cascade their knowledge to their students. Collaboration and partnerships with CHED and other non-government agencies including private industries must be designed or redesigned into the knowledge creation approach. HEIs should consider giving incentives to teachers who are trained in the use of ICT in the classroom. School leaders must continue in supporting the trained educators, and they should prioritize them in any ICT-related endeavors such as ICT in education research, instruction, community service-learning. Organizers must develop a continuing program to ensure sustainability of the acquired skills. The training resources and weekly activities must be reviewed to ensure scalability and adaptability of the learning materials especially to those who are challenged by Internet connectivity. A study to explore the barriers and difficulties in an online or hybrid method of learning is also recommended.

\section{ACKNOWLEDGEMENT}

The funding support provided by from the Commission on Higher Education through the Philippine Higher Education Research Network (PHERNet), facilitated by Silliman University through Research and Development Center is gratefully acknowledged. We would like to thank the participants during the 3rd International Conference on Advancement of Development Administration 2014 on October 9-10, 2014 at the National Institute of Development Administration (NIDA), Bangkok, Thailand for their comments and suggestions on the original version of this paper. 


\title{
REFERENCES (TRANSLATED AND TRANSLITERATED)
}

[1] EDUCAUSE. Blended learning. Retrieved November 3, 2017, from https://library.educause.edu/topics/teaching-and-learning/blended-learning, 2017.

[2] UNESCO Bangkok. Blended Learning for Quality Higher Education: Selected Case Studies on Implementation from Asia-Pacific. Retrieved November 3, 2017 from http://bangkok.unesco.org/content/blended-learning-quality-higher-education-selected-case-studiesimplementation-asia-pacific, Sep 25, 2017.

[3] M. Trucano. Knowledge Maps: ICTs in Education. Washington, DC: infoDev / World Bank. Retrieved from November from http://www.infodev.org/articles/use-specific-ict-tools-education, 2005.

[4] M. Kaur, Blended Learning - Its Challenges and Future, In Procedia - Social and Behavioral Sciences, ISSN 1877-0428, https://doi.org/10.1016/j.sbspro.2013.09.248. (http://www.sciencedirect.com/science/article/pii/S187704281303351X), vol 93, 612-617, 2013.

[5] A. Majumdar. Organizational Blended Learning - Five Common Challenges and Solutions. Retrieved from https://www.gc-solutions.net/blog/organizational-blended-learning-five-common-challenges-andsolutions/, July 16, 2015.

[6] P. Taylor \& D. Maor. The Constructivist On-Line Learning Environment Survey (COLLES). Retrieved September 15, 2014, from A Free Tool to Help Teachers Survey Students: http://surveylearning.moodle.com/colles/

[7] Florida Gulf Coast University. Evaluation of Online Course (based on Principles of Online Design. Retrieved September 16, 2014, from Principles of Online Design: http:/www.fgcu.edu/onlinedesign/

[8] B. Burnsed. Online Universities: Retention Rate Data. Retrieved September 20, 2014, from U.S. News \& World Report LP: http://www.usnews.com/education/online-education/articles/2010/10/22/onlineuniversities-retention-rate-data, 2010.

[9] D. Luzer. How Online College Could Hurt Graduation Rates. Retrieved September 21, 2014, from Washington Monthly: http://www.washingtonmonthly.com/college_guide/blog/how_online_college_could_hurt.php\#, 2012.

[10] D. Koller, A. Ng, C. Do, \& Z. Chen. Retention and Intention in Massive Open Online Courses: In Depth. Retrieved August 29, 2014, from EDUCAUSE Review Online: http://www.educause.edu/ero/article/retention-and-intention-massive-open-online-courses-depth-0, 2013.

Text of the article was accepted by Editorial Team 19.08.2017.

\section{РІВЕНЬ УСПІХУ ГІБРИДНОГО НАВЧАННЯ В ПЕДАГОГІЧНІЙ ОСВІТІ: ДОСВІД КРАЇН, ЩО РОЗВИВАЮТЬСЯ}

\author{
Дейв І. Марціал \\ доцент, PhD в освіті, декан \\ Університет Сілліман, Думагет сіті, Східний Негрос, Філіппіни \\ demarcial@su.edu.ph
}

Дае П. Хабало

магістр з адміністрування бізнесом, головний спеціаліст освітньої програми Відділення департаменту освіти Східного Негросу, Філіппіни

ORCID ID 0000-0003-1101-2130

dphabalo@gmail.com

Анотація. Дослідження показують, що змішане навчання сприяє колаборативному
навчанню. Проте змішане навчання залежить від обмеженості Інтернет-інфраструктури.
Стаття надає опис рівня успішності 6-місячного змішаного курсу навчання педагогічних
працівників у чотирьох провінціях центральної частини Філіппін. Змішані тренінги були
спрямовані на збільшення можливостей підвищити цінність економічного показника
шляхом застосування знань зі шкільних предметів для розв’язання складних проблем, що
виникають у реальних робочих і життєвих ситуаціях. Рівні успіху оцінювалися за
допомогою показника утримання, Моделі онлайн конструктивістського навчального
середовища, моделі елементів онлайн середовища й нової моделі Д. Кіркпатріка. 360 
зареєстрованих учителів, лише 15 пройшли навчання. Автори вважають, що тренінг 3 використанням змішаного навчання можна оцінити як успішний.

Ключові слова: змішаний тренінг; освітні технології; ІКТ в педагогічній освіті.

\title{
УРОВЕНЬ УСПЕХА ГИБРИДНОГО ОБУЧЕНИЯ В ПЕДАГОГИЧЕСКОМ ОБРАЗОВАНИИ: ОПЫТ РАЗВИВАЮЩИХСЯ СТРАН
}

\author{
Дэйв И. Марциал \\ доцент, $\mathrm{PhD}$ в образовании, декан \\ Университет Силлиман, Думагет сети, Восточный Негрос, Филиппины \\ demarcial@su.edu.ph
}

\section{Дает П. Хабаль}

магистр по администрированию бизнесом, главный специалист образовательной программы Отделение департамента образования Восточный Негрос, Филиппины

ORCID ID 0000-0003-1101-2130

dphabalo@gmail.com

\begin{abstract}
Аннотация. Исследования показывают, что смешанное обучение способствует колаборативной учебе. Однако смешанное обучение зависит от ограниченности Интернетинфраструктуры. Статья предоставляет описание уровня успешности 6-месячного смешанного курса обучения педагогических работников в четырех провинциях центральной части Филиппин. Смешанные тренинги были направлены на увеличение возможностей повысить ценность экономического показателя путем применения знаний по школьным предметам для решения сложных проблем, возникающих в реальных рабочих и жизненных ситуациях. Уровни успеха оценивались с помощью показателя удержания, модели онлайн конструктивистской учебной среды, модели элементов онлайн среды и новой модели Д. Киркпатрика. Из 60 зарегистрированных учителей, только 15 прошли обучение. Авторы считают, что тренинг с использованием смешанного обучения можно оценить как успешный.
\end{abstract}

Ключевые слова: смешанный тренинг; образовательные технологии; ИКТ в педагогическом образовании.

\section{(cc) BY-NC-SA}

This work is licensed under Creative Commons Attribution-NonCommercial-ShareAlike 4.0 International License. 